DOI: 10.46340/eppd.2020.7.3.20

Yana Chernopyshchuk, PhD in Law

ORCID ID: https://orcid.org/0000-0001-5306-8808

Deputy head of the economy development department at the municipality

of Bilhorod-Dniestrovsky, Odesa region, Ukraine

\title{
THE IDEA OF LOCAL SELF-GOVERNMENT IN POLAND IN THE EIGHTIES AS AN INDICATION AND POSSIBLE INSPIRATION FOR THE DECENTRALIZATION REFORM IN UKRAINE
}

\author{
Yana Chernopyshchuk \\ Doctor nauk prawnych zastępca kierownika wydziału rozwoju gospodarczego Urzędu \\ miejskiego miasta Białogród nad Dniestrem, obwód Odeski, Ukraina

\section{MYŚL SAMORZĄDOWA W POLSCE W LATACH 80CH, JAKO WSKAZÓWKA I MOŻLIWA INSPIRACJA DLA REFORMY DECENTRALIZACJI NA UKRAINIE}

\begin{abstract}
This article provides for the exploration of the core idea of local self-government in Poland in the eighties of the twentieth century, which implementation leads to the decentralization of public authority and total transformation of the state. The author exposed the main historical path of the mentioned thought in political and legal processes in Poland within 1980-1990 years, analyzed "Solidarność" movement's impact on social community awakening, summarized advantages of local self-government idea realization in Poland. In conclusion, the author presented reasons for polish self-government thought and its relevance for current decentralization reform in Ukraine.
\end{abstract}

Keywords: freedom, solidarity, self-government, decentralization.

W 2020 r. mija 30 lat od momentu ukonstytuowania się w Polsce samorządu terytorialnego (początkowo tylko gminnego) opartego na zasadach samodzielności i niezależności od struktur administracji centralnej państwa. Uważa się, że reforma samorządowa jest najskuteczniej przeprowadzoną zmianą ustrojową i najkorzystniejszą dla rozwoju państwa reformą przeprowadzoną po 1989 r. w Polsce. Stworzyła ona mocne podstawy rozwoju miast, wsi i łączących je regionów. Widoczne rezultaty tej zmiany można aktualnie obserwować w wielu dziedzinach życia począwszy od infrastruktury lokalnej, a skończywszy na projektach infrastrukturalnych na poziomie regionalnym. Finansowe wsparcie, które Polska otrzymała po wstąpieniu do Unii Europejskiej, odegrało również istotną rolę w rozwoju państwa, jego nowoczesności, poprawie warunków życia Polaków i możliwości rozwoju cywilizacyjnego w Polsce. W celu stworzenia możliwości racjonalnego wykorzystywania środków pomocowych, w chwili przystąpienia Polski do UE w 2004 r. wypełniono już niezbędne warunki samodzielnego funkcjonowania samorządów w zdecentralizowanym systemie władzy publicznej. Samorządy były przygotowane do skutecznego zaspokajania bieżących potrzeb mieszkańców, były gotowe też do podejmowania wyzwań związanych z kreowaniem otaczającego mieszkańców środowiska, w taki sposób aby inwestowane środki nie były tylko konsumowane na konieczne ,łatanie dziur" cywilizacyjnych pozostałych po czasie komunizmu a kreowały rozwój zgodnie z wolą mieszkańców.

Wydaje się, że obecnie realizowana na Ukrainie reforma decentralizacyjna w dużej mierze czerpie z polskiego modelu reformowania państwa. Wykorzystanie tej wiedz może to skutkować przyśpieszeniem reform i zaoszczędzeniem czasu rządzącym w szukaniu i kreowaniu pozytywnych rozwiązań. Dla tego warto by twórcy reformy na Ukrainie, przystępując do tak doniosłego zadania jak reforma samorządowa która jest de facto gruntowną reformą państwa, zapoznali się z przebiegiem procesów decentralizacyjnych władzy w Polsce. 
Decentralizacja władzy w Polsce, której istotną częścią była reforma samorządowa, przebiegały jednocześnie jako efekt zmian polegających na demokratycznym przekształceniu ustroju państwa. Zmiany te były możliwe po odsunięciu w pokojowy sposób od władzy komunistów w Polsce w czerwcu 1989. Jednakże koncepcja koniecznych zmian, idea przebudowy ustroju państwa oraz wprowadzenie nowego modelu zarządzania $\mathrm{w}$ administracji publicznej miały swoje początki już na początku lat 80 . XX wieku i wynikały jednoznacznie $\mathrm{z}$ obserwowanego od lat 70. XX w. procesu pogłębiania się kryzysu ekonomicznego oraz rozziewu między nastrojami społecznymi katolickiego narodu a preferowanym przez komunistów modelem społeczno-politycznym i ekonomicznym. Do powstania tego kryzysu przyczyniło się nieudolne, scentralizowane zarządzanie państwem, dodatkowo przesiąknięte komunistycznym doktrynerstwem władz PRL blokującym z zasady stosowanie jakichkolwiek liberalnych reform i zarządzaniem gospodarką na zasadach rynkowych, zastępowanie tego co podpowiadał zdrowy rozsądek próbami reformowania systemu ( wówczas określanego jako socjalistyczny) w myśl zasady, że to niezły jest system a realizujący jego założenia ludzie. Potrzeba zmian widoczna była dla ludzi zaczynających myśleć o przyszłości Polski. Byli to Stefan Mieczysław Grzybowski, Michał Kulesza, Zygmunt Niewiadomski, Walerian Pańka, Karol Podgórski, Jerzy Regulski i Jerzy Stępień. Póżniej stali się oni twórcami samorządu terytorialnego w Polsce, pelniące każdy ważną rolę w swojej dziedzinie. Przemiany polityczne, budowa samorządu terytorialnego i społeczeństwa obywatelskiego, to procesy tak mocno wzajemnie powiązane, że nie jest możliwe oddzielić ich od siebie, gdyż razem mają bezpośredni wpływ na jakość i warunki życia mieszkańców, którzy jednocześnie są twórcami i uczestnikami życia na poziomie państwowym i lokalnym. Dlatego też mieszkańcy od samego początku powinni być w te procesy wprzęgnięci.

Zdaniem Jerzego Regulskiego: „Decentralizacja to nie tylko zmiany prawne czy nawet instytucjonalne, zaprogramowane $\mathrm{w}$ parlamencie $\mathrm{i} \mathrm{w}$ rządzie. Jest to proces znacznie szerszy $\mathrm{i}$ skomplikowany. [...] Nic bowiem nie może zastąpić inicjatyw społeczności lokalnych i zaangażowania ogromnych rzesz obywateli"1.

Należy całkowicie zgodzić się z takim postawieniem sprawy. Niezbędne jest zatem wskazanie historycznego kontekstu ewolucji ustroju, zarówno w ujęciu politycznym, jak i społecznym, w dojściu do zaakceptowania i wdrażania nowych zasad samorządności na poziomie lokalnym.

Myśl samorządowa w Polsce w latach 80ch stała się oparciam dla okresu przygotowawczego do wdrożenia po 1997 roku całościowego modelu samorządu terytorialnego i przygotowania systemu administracji samorządowej do warunków w jakich miał funkcjonować po wejściu Polski do Unii Europejskiej.

W okresie PRL panowała zasada centralizmu we wszystkich dziedzinach życia. Wszelkie przejawy życia mogły być organizowane i kontrolowane tylko przez państwo. Eliminowało to możliwość istnienia jakiegokolwiek samorządu. Polska Rzeczpospolita Ludowa (PRL) była państwem scentralizowanym a jego struktura pionowa jednolita, shierarchizowana i podobna do zmilitaryzowanej. Władze gminne podlegały władzom wojewódzkim, które z kolei podlegały władzom państwowym. System ten nie dawał miejsca na jakąkolwiek autonomię. Scentralizowany system zarządzania państwem i wszystkimi przejawami życia społecznego jak i gospodarczego doprowadził do zahamowania rozwoju, załamania finansów państwa, niedoborów towarów konsumpcyjnych i biedy szerokich mas społecznych. Był to stan ciągły, prowadzący na przestrzeni lat do kolejnych kryzysów przejawiających się w strajkach i manifestacjach, krwawo thumionych z użyciem przemocy(w tym zbrojnej). Krytyce poddawano przede wszystkim cały mechanizm nakazowo-rozdzielczy, centralne planowanie, nieefektywnie zarządzanie gospodarką jako całością oraz poszczególnymi przedsiębiorstwami, rozbudowaną administrację centralną, niepewną rolę pieniądza $\mathrm{w}$ gospodarce, wadliwe funkcjonowanie banków itp ${ }^{2}$. Przełomowym momentem stało się powstanie Komitetu Obrony Robotników (KOR) w 1976 r., który szybko stał się głównym elementem sieci niezależnych inicjatyw, ogólnie objętych hasłem walki o „społeczeństwo obywatelskie”. Główną zasadą tego ruchu był antyinstytucjonalizm. Idea społeczeństwa obywatelskiego, które wymiennie nazywano społeczeństwem niezależnym czy też alternatywnym $\mathrm{w}$ stosunku do państwa, doprowadziła do powstania idei samoorganizującej się, etycznej wspólnoty decydentów. Wspólnoty nie mającej być surogatem normalnej

\footnotetext{
${ }^{1}$ Regulski J. (2000). Samorząd III Rzeczypospolitej: Koncepcje i realizacja. Warszawa, 10.

${ }^{2}$ Balcerowicz L. (1981). Od diagnozy systemy do jego reformy, [w:] Ekonomiści o reformie gospodarczej, t. I:

Cele i zakres reformy gospodarczej. (red.)U. Libury-Grzelońskiej, Warszawa, 159.

${ }^{3}$ Regulski J. (2000). Samorzad III Rzeczypospolitej: Koncepcje i realizacja. Warszawa, 29.
} 
parlamentarnej demokracji możliwym do zbudowania $\mathrm{W}$ nienormalnych warunkach dyktatury komunistycznej, lecz jako jej pełna alternatywa ${ }^{1}$.

W 1980 r. działalność KOR i walka o prawa robotników w Gdańsku, jak również początek ogólnokrajowego strajku robotników o wolność zrzeszania się w ramach związków zawodowych, umożliwił stworzenie i rejestracji Niezależnego Samorządnego Związku Zawodowego „Solidarność”. Związek ten oprócz funkcji typowych dla organizacji robotników reprezentującej ich w stosunku do pracodawcy, czyli państwa w warunkach gospodarki scentralizowanej, był platformą skupiającą środowiska niepodległościowe oraz ludzi myślących o tym, jak trzeba będzie państwo zorganizować po upadku komunizmu, bo o tym też myślano. Właśnie w środowisku zwolenników idei solidarności społecznej powstały odpowiednie warunki do wymiany myśli pomiędzy entuzjastami idei samorządowej. Doprowadziło to do podjęcia wstępnych studiów na temat samodzielnych wspólnot lokalny. Ruch „Solidarności” był ośrodkiem kształtowania potrzebnych i korzystnych idei dla społeczeństwa nie tylko polskiego, ale i społeczeństw żyjących w reżimach komunistycznych w innych państwach Europy Środkowo-Wschodniej. „Solidarność” wyrosła na walce o prawa pracownicze, ale w rzeczywistości była odbierana przez społeczeństwo jako szeroki ruch społeczny stojący w opozycji do komunistycznej władzy i jako miejsce walki o zmiany ustrojowe. W pierwszym rzędzie o rozluźnienie komunistycznej supremacji, a w konsekwencji zrzucenie komunistycznego jarzma i radykalnej zmiany ustrojowej. Hasłem tamtych czasów wyrażającym istotę ruchu „Solidarności” były słowa wypowiedziane przez papieża Jana Pawła II w czasie pielgrzymki w 1983 r. do Polski: „Nie ma wolności bez solidarności!"’. "Solidarność" stałą się synonimem wolności przejawiającą się w ludzkiej wspólnocie. To hasło powtórzyła w swojej pierwszej winiecie „Gazeta Wyborcza” debiutująca w maju 1989 r., jeszcze przed czerwcowymi wyborami. Hasło miało wyrażać chęć budowy nowego państwa opartego na demokracji i wspólnocie ${ }^{3}$. Akcentowano w ten sposób nie priorytet państwa, a tworzących obywateli państwo. Rozmyślano nad koncepcją zmian ustrojowych. W ówczesnych realiach nie było jednak mowy o całkowitej likwidacji komunizmu. Dyskusja ta była jednak instrument do zwrócenia uwagi na potrzeby wspólnotowe obywateli, wezwanie władzy do dialogu z obywatelami o nowych formach ustrojowych, w których głos obywatelski jest słyszalny, a przez to mający wpływ na władzę.

Dokument, który otworzył drogę w stronę przemian w budowie samorządu, został przedstawiony w dniu 12 czerwca 1981 r. na forum Komisji Prawa i Praworządności Konwersatorium „Doświadczenie i Przyszłość”. Zawierał on następujące tezy: „(...) nie jest możliwe wyjście z kryzysu politycznego, społecznego i gospodarczego kraju bez generalnej reformy władz terenowych, bez przywrócenia im autentycznego samorządu, niezbędnego dla wyzwolenia aktywności społeczeństwa i dla uruchomienia ogromnych rezerw inicjatyw społecznych" ". To wówczas naukowcy teorii rozwoju samorządów w Polsce z Uniwersytetu Łódzkiego sformułowali podstawowe postulaty nowej koncepcji samorządnego społeczeństwa. Pisali oni: „Stwierdziliśmy, że samorząd terytorialny ma do odegrania rolę nie tylko gospodarczą, ale również polityczną i społeczną. Wymaga ona stworzenia warunków władzom lokalnym do samodzielnego działania, a więc samodzielnego określania celów rozwoju lokalnego, określania dróg ich osiągania, gromadzenia i dysponowania środkami finansowymi i własnym majątkiem, swobodnego korzystania z przysługujących praw i ustalania przepisów lokalnych"s.

Związek „Solidarność” obudził aktywność społeczną, skoncentrował w ramach tworzonego przez siebie forum przedstawicieli inteligencji, przedstawicieli robotników, kształtując w naturalny sposób zalążki prawidłowego społeczeństwa obywatelskiego, ze współpracującymi ze sobą różnymi, ale równymi i wolnymi obywatelami dla dobra publicznego. Tytuł uchwały programowej sformułowany podczas I Krajowego Zjazdu Delegatów NSZZ „Solidarność” we wrześniu 1981 r. brzmiał: „Samorządna Rzeczpospolita”. W tezie 22. tego programy zapisano: „Samorządne prawnie, organizacyjnie i majątkowo

\footnotetext{
${ }^{1}$ Ibidem, 31.

${ }^{2}$ Portal historyczny. $<$ https://dzieje.pl/node/44714> (2016, lipiec, 21).

${ }^{3}$ Gazeta Wyborcza” wraca do hasła „Nie ma wolności bez solidarności”.

$<$ https:/www.wirtualnemedia.pl/artykul/gazeta-wyborcza-haslo-nowe-w-winiecie-nie-ma-wolnosci-bez-solidarnosci> (2019, lipiec, 29).

${ }^{4}$ Regulski J., Bury P., Jewtuchowicz A., Markowski T. Dokument nr 3: Konwersatorium „Doświadczenie i Przyszłość”.

$<$ http://www.dlibra.karta.org.pl/dlibra/doccontent?id=1418 > (2019, grudzień, 11).

${ }^{5}$ Regulski J. (2000). Samorząd III Rzeczypospolitej: Koncepcje i realizacja. Warszawa, 34.

${ }^{6}$ I Krajowy Zjazd Delegatów NSZZ „Solidarność”. (1981). Statut, Uchwala Programowa z Aneksem. Gdańsk.

Biuro Informacji Prasowej Komisji Krajowej NSZZ „Solidarność”.
} 
samorządy terytorialne muszą być rzeczywistą reprezentacją społeczności lokalnej”1. Przez teoretyków zgrupowanych wokół „Solidarności” samorząd był wyrazem i formą współdziałania ludzi, a nie częścią administracji publicznej. Konsekwencją takiego rozumienia samorządu było późniejsze podejście do opracowań modeli samorządowych w Polsce, a jako rezultat usankcjonowany prawnie podział administracji publicznej na rządową i samorządową. Warto zaznaczyć, że głównymi autorami prac w zakresie reformy władz lokalnych zostali teoretycy Instytutu Nauk Ekonomicznych PAN (Zakład Gospodarki Regionalnej), Uniwersytetu Łódzkiego (Zakład Ekonomiki Rozwoju Miast), Wydział Prawa Uniwersytetu Warszawskiego (Michał Kulesza).

Edukacja społeczeństwa w zakresie procesu przekształceń odbywała się na łamach tygodników „Wspólnota” i „Samorząd terytorialny” w ramach działań podejmowanych przez Międzykomunalną Spółkę Municipium, a także przy szerokiej aktywności Fundacji Rozwoju Demokracji Lokalnej².

Szczególnie cenną platformę wymiany myśli w przedmiotowym zakresie stworzyli księża jezuici i redakcja periodyku pt. „Przegląd Powszechny”. Ponadto, został wysłany list Episkopatu Polski do przewodniczącego komisji sejmowej, która przygotowywała zmiany ustawowe stwierdzający, że obecny system jest „nieefektywny i nie tworzy fundamentów porozumienia narodowego" 3 . W taki sposób społeczność katolicka zaakcentowała ówczesnym władzom komunistycznym nieodwracalność fundamentalnych reform. Tym sposobem dołączyła do opozycji demokratycznej walczącej o głębokie zmiany ustrojowe.

Ruch solidarnościowy stał się dla Polski źródłem powstania społeczeństwa obywatelskiego, obudził on ludzi do wspólnego działania, do otwartej dyskusji z ówczesną władzą, wbrew cenzurze, krwawemu stanowi wojennemu i delegalizacji „Solidarności” oraz represji przez kolejne lata. W 1988 r. nieugięta postawa społeczeństwa doprowadziła do dyskusji przy „Okrągłym Stole” tj. opozycji z rządzącymi. Zwróciło to na Polskę uwagę państw demokratycznych, od których otrzymała ona później mocne poparcie ideologiczne i finansowe. Opozycyjne środowisko wzmacniało się lawinowo $\mathrm{z}$ jednoczesną widoczną erozją i słabnięciem komunistycznego reżimu nie mającego nic do zaoferowania społeczeństwu, w wyniku kompletnego krachu nieudolnie prowadzonych reform gospodarczych i zapaści ekonomicznej. Wyrazem negatywnego nastawienia społeczeństwa do komunistów i ich rządów była reakcja widzów po przegranej debacie telewizyjnej, która odbyła się 30 listopada 1988 r. pomiędzy komunistycznym liderem reżimowej organizacji pracowniczej pod nazwą Ogólnopolskiego Porozumienia Związków Zawodowych (OPZZ) Alfreda Miodowicz z Lechem Wałęsą przywódcą „Solidarności" ${ }^{4}$. Zwykli ludzie składali sobie gratulacje, było jasne że „komuna sypie się”, ze jest nadzieja na normalność. Pojawiła się zapowiedź „okrągłego stołu”, czyli negocjacji pomiędzy opozycją a władzą. Stół przy którym odbyły się negocjacje faktycznie miał kształt okrągły, co miało podkreślić równość stron dyskusji. To był przełomowy, historyczny moment i okazja do wypracowania propozycji do rozpoczęcia fundamentalnych zmian ustroju państwowego na kształt demokratycznych państw, w tym stworzenie samorządu terytorialnego. Po ośmiu latach od wprowadzenia stanu wojennego mającego na celu spacyfikowanie „rozmarzonego w wolności społeczeństwa” i próbie zniszczenia zalążków myśli samorządowej stało się zrozumiałe dla wszystkich, że ostateczne złamanie schematu scentralizowanej piramidy kontroli wszystkiego i wszystkich nie uda się bez powstania samorządnych gmin, a najprościej mówiąc przekazaniu obywatelom władzy tam gdzie mieszkają i żyją.

Sformowany w grudniu 1988 r. Komitet Obywatelski przy NSZZ „Solidarność” wystąpił jako ciało negocjujące $\mathrm{z}$ partią i rządem. W ramach podstawowego zespołu reform politycznych skupiono się na legalizacji NSZZ „Solidarność” oraz na swobodach obywatelskich, w tym i na dostępie do środków masowego przekazu, swobody wydawania prasy, wolności stowarzyszeń i zgromadzeń. Najbardziej ambitnym punktem programu „Solidarności” był postulat reformy samorządu terytorialnego, punkt ten napotkał jednak na nieustępliwość strony rządowej ${ }^{5}$. Na posiedzeniach „Okrągłego Stołu” na początku 1989 r. Komisja Samorządowa Komitetu Obywatelskiego w trudnych konfrontacyjnych rozmowach ze

\footnotetext{
${ }^{1}$ Ibidem.

${ }^{2}$ Regulski J. (2000). Samorzad III Rzeczypospolitej: Koncepcje i realizacja. Warszawa, 85-87.

${ }^{3}$ Dokument nr 11: List Episkopatu Polski w sprawie projektu ustawy o radach narodowych i samorządzie terytorialnym. (2000). Reforma samorządowa. Materiały źródłowe 1980-1990, (wstęp i wybór) J. Regulski, Warszawa, 118.

${ }^{4}$ Nieudana marmolada z Wałęsy. (2009). W: Historia PRL. T. 24: 1988. New Media Concept, 18-19.

${ }^{5}$ Matyja R. Przebudowa państwa. (2013). Czas wielkich zmian. Antologia „Polityki Polskiej”. Red. M. Bartyzel, A. Wołek, Warszawa, 221.
} 
stroną rządową przedstawiła na piśmie ultimatum formułując trzy postulaty, które nie mogły podlegać żadnym negocjacjom:

- zagwarantowanie prawnie odrębności samorządu, przy ograniczeniu kontroli rządowej jedynie do kwestii legalności decyzji,

- niezależność finansowa,

- demokratyczne wybory ${ }^{1}$.

Nie udało się jednak tych postulatów obronić i uzyskać zgody strony rządowej. W przypadku bowiem ich zrealizowania, taki model lokalnego samorządu oznaczałby koniec ustroju komunistycznego, na co władza nie mogła się zgodzić. Jednak cytując słowa jednego z członków Komisji Komitetu Obywatelskiego „dyskusje przy „Okrągłym Stole” to nowy etap w historii odbudowy samorządu”. Nieprzygotowanie opozycji do przejęcia władzy skutkowała tym, że dwie reformy, mianowicie gospodarcza i samorządowa były przygotowane niezależne poza "Solidarnością". Twórcy reformy nie mieli wtedy dostępu do praktyki działania i informacji o finansach państwa, dlatego opierali się w reformie głównie na doświadczeniach zagranicznych, starając się zastosować to na polskim gruncie ${ }^{3}$.

W trakcie kampanii wyborczej do polskiego parlamentu w 1989 r. opozycja antykomunistyczna zaczęła działać również w terenie. Aktywna samoorganizacja społeczeństwa doprowadziła do tworzenia lokalnych komitetów obywatelskich organizowanych z ludzi, którzy chcieli wziąć aktywny udział w przebudowie kraju. Po wyborach rozpoczęto kampanię edukacyjną i doradczą polegającą na thumaczeniu władzy lokalnej szczegółów nowego modelu samorządowego. Idea polegała na tym, żeby przebudowa ustrojowa szła od dołu na podstawie aktywnych działań wspólnot lokalnych (w tym czasie w postaci Społecznego Ruchu Samorządności Obywatelskiej „Solidarność”) bez żadnego narzucania metod i sposobów sprawowania lokalnych działań. Wzmacnianie wspólnot lokalnych odbywało się poprzez działania Komisji Samorządu Terytorialnego Komitetu Obywatelskiego. Działalność okazała się skuteczna, gdyż „Solidarność" otrzymała większość w Senacie. Po wyborach, nastąpiła rozbudowa idei samorządów i nowego demokratycznego ustroju Polski. Proces mógł być już inspirowany centralnie, ponieważ „Solidarność” przy poparciu społeczeństwa otrzymała legitymizację sprawowania władzy.

We wrześniu 1989 r. Rada Ministrów ustanowiła Urząd Pełnomocnika Rządu do spraw Reformy Samorządu Terytorialnego w rządzie Tadeusza Mazowieckiego. Urząd ten miał za zadanie prowadzić reformę na trzech płaszczyznach:

- legislacyjnej, dotyczącej zmiany ustroju prawnego państwa,

- społecznej, mającej za zadanie przygotowanie społeczeństwa do podejmowania nowych zadań i ponoszenia za nie odpowiedzialności,

- instytucjonalnej, mającej za zadanie przebudowę istniejącego stanu rzeczy jeśli chodzi o organizację państwa ${ }^{4}$.

W krótkim czasie przygotowano podstawowe akty prawne dotyczące ustroju i etapy realizowania reformy samorządowej. W dniu 8 marca 1990 r. uchwalone zostały zmiany w Konstytucji PRL. Wprowadzono nowy rozdział poświęcony samorządowi i pojęcie administracji rządowej, w tym wojewody jako jej przedstawiciela $\mathrm{w}$ terenie ${ }^{5}$.

W przeciągu dwóch kolejnych miesięcy parlament uchwalił ustawy, które gruntownie zmieniały dotychczasowy stan prawny dotyczący funkcjonowania gmin. Ponadto, mocą Ustawy o samorządzie terytorialnym z dnia 8 marca 1990 r. gminy uzyskały osobowość prawną i samodzielność, które podlegały ochronie sądowej. Nadano im możliwość wykonywania zadań administracji publicznej w terenie. Gmina była rozumiana jako wspólnota samorządowa tworzona z mocy prawa przez mieszkańców oraz jako odpowiednie terytorium. Wyodrębniono budżet gminny z budżetu państwa ${ }^{6}$. Nie stanowiono jeszcze wprost o zasadzie decentralizacji, chociaż budowa samorządów oznaczała wyjście wspólnot lokalnych spod totalnej kontroli administracji rządowej. Na takie otwarte zadekretowanie decentralizacji nie pozwalała dostatecznie mocna pozycja ówcześnie rządzących wywodzących się z opozycji czasu komunistycznego.

\footnotetext{
${ }^{1}$ Regulski J. (2000). Samorzą III Rzeczypospolitej: Koncepcje i realizacja. Warszawa, 55.

${ }^{2}$ Regulski J. (1989). Okrągły stół. Kto jest kim. Opozycja. Warszawa, 281.

${ }^{3}$ Ibidem.

${ }^{4}$ Dokument nr 25: Notatka prof. Jerzego Regulskiego dla premiera Tadeusza Mazowieckiego (2000).

Reforma samorządowa. Materiały źródłowe 1980 - 1990, (wstęp i wybór) J. Regulski, Warszawa, 31.

${ }^{5}$ Ustawa z 8 marca 1990 o zmianie Konstytucji RP, (Dz. U. z 1990 r. Nr 16, poz. 94).

${ }^{6}$ Art.1 Ustawy z dnia 8 marca 1990 r. o samorządzie terytorialnym, (Dz. U. z 1990 r. Nr 16, poz. 95).
} 
Oficjalnie decentralizacja została wyartykułowana dopiero siedem lat później w nowej Konstytucji Rzeczpospolitej Polskiej z dnia 2 kwietnia 1997 roku.

Opisany powyżej proces reformy samorządowej osiągnął swój szczytowy moment w dniu 27 maja 1990 r., czyli podczas pierwszych demokratycznych wyborów w Polsce do rad gminnych. Wybory te odbyły się na podstawie ustawach o samorządzie gminnym z dnia 8 marca 1990 roku i nowej Ordynacji wyborczej uchwalonej tego samego dnia. Odstęp czasu pomiędzy uchwaleniem prawa a datą przeprowadzenia wyborów uzmysławia tempo podjętych zmian. Były one konsekwencją przemian społeczno- gospodarczych podjętych po 1989 roku$^{1}$. Ten akt wyborczy społeczeństwa stanowił kolejny krok na drodze do budowania nowej, wolnej Rzeczypospolitej.

Wybory samorządowe oraz reformy prawa z nimi związane wprowadzono po to, aby zastąpić wywodzące się z czasów PRL rady narodowe demokratycznie wybieranymi radami gmin. Wyborcy głosowali na kandydatów na radnych, czyli osoby mające objąć mandat w radach gmin (w miastach - rady miejskie). Wybory przeprowadzono do 2383 rad gmin. W celu przeprowadzenia wyborów utworzono 47.997 okręgów wyborczych w tym 47.254 jednomandatowych i 743 wielomandatowe. Frekwencja wyborcza wyniosła 42,27\% uprawnionych do głosowania ${ }^{2}$. W lokalnych wyborach ok. $53.1 \%$ otrzymały Komitety Obywatelskie „Solidarność”3.

W polączeniu z większością przedstawiceli "Solidarności" w Senacie zwycięstwo w terenie doprowadziło do nowego politycznego ukształtowania władzy z demokratycznie wybranych przedstawicieli społeczeństwa Polskiego zorientowanego na program zmian cywylizacyjnych $\mathrm{w}$ państwie zgodny z zasadami decentralizacji władzy.

Jednym z ciekawszych zjawisk związanych z rozwojem samorządności w Polsce jest fakt, że samorządy stały się miejscem kształtowania nowych elit politycznych oraz społeczeństwa obywatelskiego. Proces ten rozpoczął się zaraz po wyborach do nowych, nieznanych społeczeństwu z przeszłości organów władzy, jakim były w ustroju państwa - rady gmin. Mieszkańcy zaangażowani w sprawy wspólnoty poprzez udział w samorządzie gminnym otrzymali mandat zaufania społecznego i w konsekwencji stali się znaczącą siłą polityczną. Radni z nowo powstałych rad nie byli silnie upartyjnieni. Jednocześnie polityka nowego rządu nie była jednoznacznie przyjazna samorządom i ewoluowała wraz ze zmianą władzy politycznej. Przedstawiciele samorządów byli zainteresowani przechodzeniem do polityki krajowej. Celem było wywieranie wpływu na politykę państwa, tak aby wzmacniać w nim rolę samorządów.

Twórcy modelu samorządowego w Polsce stwierdzili, że: „Nie wystarczy mieć cel, trzeba jeszcze wiedzieć, jak ten cel osiągnąć" . Opisany powyżej mechanizm osiągnięcia tego celu zadziałał znakomicie doprowadzając społeczeństwo do powstania samorządowej Polski. Jak podkreślił J. Regulski: „Państwo powinno zając się tym, czym musi, tym, czym nie musi, lepiej zajmie się obywatel”. To jest właśnie fundament samorządowego modelu państwa wypracowanego w Polsce.

Na podstawie przedstawionej powyżej genezy można dojść do wnisku, że reforma samorządowa była aktem niezależnym wynikającym z potrzeb społecznych, przeprowadzonym na fali ruchu fundamentalnych zmian w całym kraju. To stanowiło o sile tej reformy mającej swoje źródło w masowej aktywności obywatelskiej. Dało to jej moc do przetrwania niezależnie od aktualnego rozkładu sił politycznych na szczeblu centralnym. Sił, które już w wolnej Polsce nie zawsze były samorządności przychylne tak jak to stało się po przejęciu władzy przez postkomunistów spod znaku socjaldemokracji. Reforma samorządowa była kontynuowana niezależnie od zmian sił politycznych w Polsce. W ramach reformowania państwa liderzy ruchu "Solidarność", po wygranych wyborach (częściowo demokratycznych) w 1989 r. opowiadali się za całkowitym odrzuceniem scentralizowanego modelu życia społeczno-politycznego, proponując zbudowanie od nowa struktur samorządowych. Przez 30 lat Polska samorządowa udowodniła, że prowadzi skutecznie państwo po drodze rozwoju, a samorządowe zasady decentralizacji, pomocniczości, samodzielności stały się jednym z gwarantów stabilności Rzeczypospolitej Polski.

\footnotetext{
${ }^{1}$ Kletke O. Krótka historia pierwszych wyborów samorządowych w Polsce.

<http://wiadomosci.gazeta.pl/wiadomosci/7,114884,23236249,krotka-historia-pierwszych-wyborow-samorzadowychw-polsce.html> (2018, kwiecień. 10).

${ }^{2}$ Obwieszczenie Generalnego Komisarza Wyborczego z dnia 31 maja 1990 r. o zbiorczych wynikach wyborów do rad gmin na obszarze kraju, przeprowadzonych w dniu 27 maja 1990 r., (M.P. z 1990 r. Nr 21, poz. 170).

$<$ http://prawo.sejm.gov.pl/isap.nsf/download.xsp/WMP19900210170/O/M19900170.pdf> (2018, kwiecień. 10).

${ }^{3}$ Ibidem.

${ }^{4}$ Regulski J. (2000). Samorząd III Rzeczypospolitej: Koncepcje i realizacja. Warszawa, 45.
} 
Fundamenty samorządu terytorialnego są stale aktualne, potwierdzają zasadność obranego 30 lat temu kierunku. Z solidarności i zrzeszania się ludzi wokoło idei wolności wyrosło niepodległe państwo, a samorządy stały się efektem i gwarantem tej wolności, możliwości tworzenia i funkcjonowania instytucji społeczeństwa obywatelskiego.

W taki sposób Wolność-Solidarność-Samorządność stanowią filary każdego współczesnego europejskiego państwa. Tylko tam gdzie ludzie mogą swobodnie wybierać, świadome decydować o kierunkach rozwoju istnieje demokracja, demokracja bezprzymiotnikowa, a nie jej autorytarny reżim w stylu „demokracja ludowej”, demokracja która wyrasta z poziomu wspólnoty lokalnej i pnie się do góry na szczyty władzy w państwie, łamie monopole krępujące rozwój państwa, ustanawia wolność w imię solidarności. I to jest właśnie to co wyraźnie można obserwować w rozwoju Polski przez ostatnie 20 lat.

Ukraina, jako reformujące się intensywnie państwo Europy Wschodniej, której społeczeństwo jasno wyraziło w 2014 roku swoją orientację na integrację z Unią Europejską, również powinna posiadać za opokę samorządności jasno zdefiniowane jej zasady z uwzględnieniem silnej roli wspólnoty lokalnej mieszkanców. Z tego powodu twórcy ukraińskiej reformy decentralizacji i samorządu terytorialnego oraz ukraiński ustawodawca powinni przejrzyście i jednoznacznie zdefiniować i przyjąć zasady decentralizacji, pomocniczości i samodzielności. Nie ma drugiej drogi co jasno widać na przykładzie doświadczeń polskich.

\section{References:}

1. Balcerowicz L. (1981). Od diagnozy systemy do jego reformy [Ekonomiści o reformie gospodarczej], I: Cele i zakres reformy gospodarczej. Warszawa. [in Polish].

2. Wirtualnemedia (2019). Gazeta Wyborcza” wraca do hasta „Nie ma wolności bez solidarności” $<$ https://www.wirtualnemedia.pl/artykul/gazeta-wyborcza-haslo-nowe-w-winiecie-nie-ma-wolnosci-bez-solidarnosci> (2020, May, 29). [in Polish].

3. Dokument nr 11: List Episkopatu Polski w sprawie projektu ustawy o radach narodowych i samorządzie terytorialnym. (2000). Reforma samorządowa. Materiały źródłowe 1980-1990, (wstęp i wybór) J. Regulski, Warszawa. [in Polish].

4. Dokument nr 25: Notatka prof. Jerzego Regulskiego dla premiera Tadeusza Mazowieckiego (2000). Reforma samorządowa. Materiały źródłowe 1980 - 1990, (wstęp i wybór) J. Regulski, Warszawa. [in Polish].

5. Kletke, O. (2018). Krótka historia pierwszych wyborów samorządowych w Polsce. $<$ http://wiadomosci.gazeta.pl/wiadomosci/7,114884,23236249,krotka-historia-pierwszych-wyborowsamorzadowych-w-polsce.html> (2020, May. 10). [in Polish].

6. I Krajowy Zjazd Delegatów NSZZ „Solidarność”. (1981). Statut, Uchwala Programowa z Aneksem. Gdańsk. Biuro Informacji Prasowej Komisji Krajowej NSZZ „Solidarność”. [in Polish]

7. Matyja, R. (2013). Przebudowa państwa. Czas wielkich zmian. Antologia „Polityki Polskiej”. Warszawa, $215-247$. [in Polish].

8. Nieudana marmolada z Wałęsy. (1988). Warszawa: Historia PRL. New Media Concept, 24, 18-19. [in Polish]

9. Prawo (1990). Obwieszczenie Generalnego Komisarza Wyborczego z dnia 31 maja 1990 r. o zbiorczych wynikach wyborów do rad gmin na obszarze kraju, przeprowadzonych w dniu 27 maja 1990 r., (M.P. z 1990 r. Nr 21, poz. 170). $<$ http://prawo.sejm.gov.pl/isap.nsf/download.xsp/WMP19900210170/O/M19900170.pdf> [in Polish].

10. Dzieje.pl (2016). Portal historyczny <https://dzieje.pl/node/44714> (2020, May, 21). [in Polish].

11. Regulski, J., Bury, P., Jewtuchowicz, A., Markowski, T. (2019). Dokument nr 3: Konwersatorium „Doświadczenie i Przyszłość" <http://www.dlibra.karta.org.pl/dlibra/doccontent?id=1418> (2020, May, 11). [in Polish].

12. Regulski, J. (1989). Okragły stót. Kto jest kim. Opozycja. Warszawa. [in Polish].

13. Regulski, J. (2000). Samorząd III Rzeczypospolitej: Koncepcje i realizacja. Warszawa. [in Polish].

14. Ustawy z dnia 8 marca 1990 r. o samorządzie terytorialnym. Dz. U. z 1990 r. Nr 16, poz. 95. [in Polish].

15. Ustawa z 8 marca 1990 o zmianie Konstytucji RP. Dz. U. z 1990 r. Nr 16, poz. 94. [in Polish]. 